\title{
Intraguild interactions between the predatory hoverfly Episyrphus balteatus (Diptera: Syrphidae) and the Asian ladybird, Harmonia axyridis (Coleoptera: Coccinellidae): Effect of larval tracks
}

\author{
RAKi ALMOHAMAD, FrançoIs J. VERHEGGEN, FrÉDÉRIC FRANCIS and ERIC HAUBRUGE
}

Department of Functional and Evolutionary Entomology, Gembloux Agro-Bio Tech, Liège University, Passage des Déportés 2, B-5030 Gembloux, Belgium; e-mail: entomologie@fsagx.ac.be

Key words. Syrphidae, Coccinellidae, Episyrphus balteatus, Harmonia axyridis, larval tracks, Vicia faba, aphids, oviposition-deterring substances

\begin{abstract}
The effects of the larval tracks of Episyrphus balteatus DeGeer (Diptera: Syrphidae) and Harmonia axyridis Pallas (Coleoptera: Coccinellidae) on the egg laying behavior of females of the predatory hoverfly E. balteatus were investigated in two-choice experiments. The oviposition response of $H$. axyridis to larval tracks of E. balteatus was also tested in one-choice experiments. Gravid E. balteatus females laid significantly fewer eggs on leaf discs with aphids and contaminated with tracks of conspecific or heterospecific larvae than on control leaf discs. H. axyridis females laid similar numbers of eggs in Petri dishes with aphids and contaminated with the tracks of E. balteatus larvae as in control Petri dishes. This indicates that $E$. balteatus females lay fewer eggs at sites where there are conspecific and heterospecific larval tracks, whereas the tracks of the syrphid larvae did not deter $H$. axyridis females from laying eggs.
\end{abstract}

\section{INTRODUCTION}

Aphidophagous hoverflies and ladybirds are known to exploit temporary aphid colonies as food resources and significantly suppress aphid abundance (Chambers \& Adams, 1986; Dixon, 1985; Dixon et al., 1997; Lee \& Kang, 2004). It has been also demonstrated that the survival of the larvae of these aphid predators and their efficiency in reducing aphid populations mainly depends on the quality and the quantity of the patches of aphid prey (Kan, 1988; Hemptinne et al., 1993; Kindlmann \& Dixon, 1993; Almohamad et al., 2007, 2008). The selection of oviposition sites by gravid females should therefore reflect a preference for patches of prey of high nutritional value and/or where the risks of predation and competition are low, especially in insect species where neonate offspring have limited mobility and are therefore relatively sessile (e.g. syrphid larvae, Chandler, 1969).

Several authors have shown that ovipositing insect predators respond to chemical cues (i.e. ovipositiondeterrents) indicating that a prey patch is already being exploited by conspecific larvae (Růžička, 1994, 1996, 1997; Doumbia et al., 1998; Růžička \& Havelka, 1998; Yasuda et al., 2000; Oliver et al., 2006; Michaud \& Jyoti, 2007). Most of these studies have focused on coccinellids and chrysopids, while studies on syrphids are very recent and scarce (e.g. Scholz \& Poehling, 2000; Pineda et al., 2007; Almohamad et al., 2008; Putra et al., 2009).

Larvae of predatory hoverflies and ladybirds occur on the same aphid infested plants and strongly interact with each other when their aphid prey becomes scarce (e.g., Agarwala \& Yasuda, 2001). The multicoloured Asian ladybird, H. axyridis is native to South-East Asia (e.g. Dobzhansky, 1933; Kuznetsov, 1997). It was introduced as biological control agent in Belgium in 1997 and by 2006 was recorded in all regions of Belgium (for an earlier survey see Adriaens et al., 2003). The hoverfly $E$. balteatus is usually the most abundant syrphid aphid predator in Europe, where it naturally occurs in high numbers in numerous crops (Tenhumberg \& Poehling, 1991; Gilbert, 1993; Colignon et al., 2001; Miñarro et al., 2005). These two aphid predators are known to be important biocontrol agents of aphid populations (Chambers \& Adams, 1986; Chambers, 1988; Koch, 2003; Roy et al., 2006; Pineda \& Marcos-García, 2008).

Pell et al. (2008) have reported that $H$. axyridis remains in equilibrium with its co-evolved native guild of predators through niche complementarity, but outside Asia the native guild of predators have co-evolved without $H$. axyridis. Recent observations also suggest that this species is now invading (semi-)natural ecosystems in Belgium and is a potential threat to native ladybird species and other aphid predators (Adriaens et al., 2003). Field observations have shown that $H$. axyridis and $E$. balteatus often coexist in aphid colonies in different habitats in BelgiumGembloux (Alhmedi et al., 2007). The objective of this study was to obtain a better understanding of the mechanisms that shape guilds of aphidophagous predators and their potential use in biocontrol. In particular, the effect of the larval tracks of E. balteatus and $H$. axyridis on oviposition-site selection by E. balteatus females was determined. The oviposition response of $H$. axyridis females to tracks left by E. balteatus larvae was also investigated. 


\section{MATERIAL AND METHODS}

\section{Plant and insect rearing}

Broad-bean plants (Vicia faba L.) were grown in $30 \mathrm{~cm} \times 20$ $\mathrm{cm} \times 5 \mathrm{~cm}$ plastic trays filled with a mixture of perlite and vermiculite (1/1) and maintained in controlled-environment growth rooms $\left(16 \mathrm{~L}: 8 \mathrm{D} ; 20 \pm 1{ }^{\circ} \mathrm{C}\right)$. Two aphid species (Myzus persicae Sulzer and Megoura viciae Buckton) were reared on broadbean plants in separate rooms. Adult E. balteatus were reared in $75 \times 60 \times 90 \mathrm{~cm}$ cages provided with bee-collected pollen, sugar and water. Broad-bean plants infested with M. viciae were introduced into the cages for $3 \mathrm{~h}$ every two days for the adults to lay their eggs on. Hoverfly larvae were mass-reared in aerated plastic boxes $(110 \times 140 \times 40 \mathrm{~mm})$ and fed daily ad libitum with M. viciae.

H. axyridis adults were obtained from Montreal Canada (Eric Lucas laboratory, Université du Québec à Montréal). Adults and larvae were then mass-reared in aerated plastic boxes (up to 25 individuals per container) and fed daily ad libitum with $M$. viciae. Bee-collected pollen, sugar and water were also provided. Boxes were placed in controlled-environment incubators $\left(25 \pm 2{ }^{\circ} \mathrm{C} ; 70 \% \mathrm{RH}\right.$ and photoperiod 16L: 8D). Mated and fertile females used in the experiment were isolated individually in separate boxes; no oviposition occurred in the $24 \mathrm{~h}$ prior to experimentation.

\section{EXP 1. Effect of conspecific and heterospecific larval tracks} on syrphid oviposition

This experiment was conducted using aphids on leaf discs (Almohamad et al., 2006). A $2.5 \mathrm{~cm}$-diameter circular piece of V. faba leaf was cut and placed in a Petri dish containing agar solution ( $7 \mathrm{ml}$ agar, $1 \%$ water solution $\mathrm{w}: \mathrm{w})$, which increased the humidity and prevented the leaf disc from drying out. Prior to use, either two third-instar larvae of E. balteatus, or two fourth-instar larvae of $H$. axyridis were confined with an excess of M. persicae (125 individuals) on each leaf-disc by parafilm paper (Parafilm ${ }^{\circledR}$, Pechiney Plastic Packaging, Chicago, USA) and kept in the controlled incubator $\left(16 \mathrm{~L}: 8 \mathrm{D} ; 20 \pm 1{ }^{\circ} \mathrm{C}\right)$ for 24 $\mathrm{h}$. After $24 \mathrm{~h}$ the larvae and all aphid material were carefully removed. Then, each leaf disc with the tracks left by syrphid or coccinellid larvae was infested with an excess of recently collected M. persicae (125 individuals). The control consisted of a leaf disc infested with the same numbers of aphids but lacking larval tracks. In a two-choice experiment, both treated and control leaf-discs (i.e. with and without larval tracks) were positioned on two Plexiglass holders 20 -cm high, separated by 15 $\mathrm{cm}$, in a net cage $(30 \times 30 \times 60 \mathrm{~cm})$. This arrangement was previously used to evaluate the oviposition response of $E$. balteatus to aphid-infested plants (Almohamad et al., 2006). A single female was then introduced into the cage and allowed to lay eggs for $3 \mathrm{~h}$. The number of eggs laid on each leaf disc was then counted. These experiments were conducted in an airconditioned room at $21 \pm 1{ }^{\circ} \mathrm{C}$. Episyrphus balteatus females were approximately 20-30 days old, and had not oviposited during the previous $24 \mathrm{~h}$. There were ten replicates of each treatment (one assessing the control leaf discs vs. those with larval tracks of E. balteatus, and the other control leaf discs vs. those with larval tracks of $H$. axyridis).

\section{EXP 2. Effect of tracks of syrphid larvae on $\boldsymbol{H}$. axyridis ovi- position}

Ten third-instar hoverfly larvae were supplied with an excess of a mixture of different instars of $M$. viciae aphids (150 individuals) in a $9 \mathrm{~cm}$-diameter glass Petri dish, the base of which was covered with filter paper. After $24 \mathrm{~h}$ the larvae and all aphid material were carefully removed. In a no-choice experiment, a single mated $H$. axyridis female was then placed in each dish

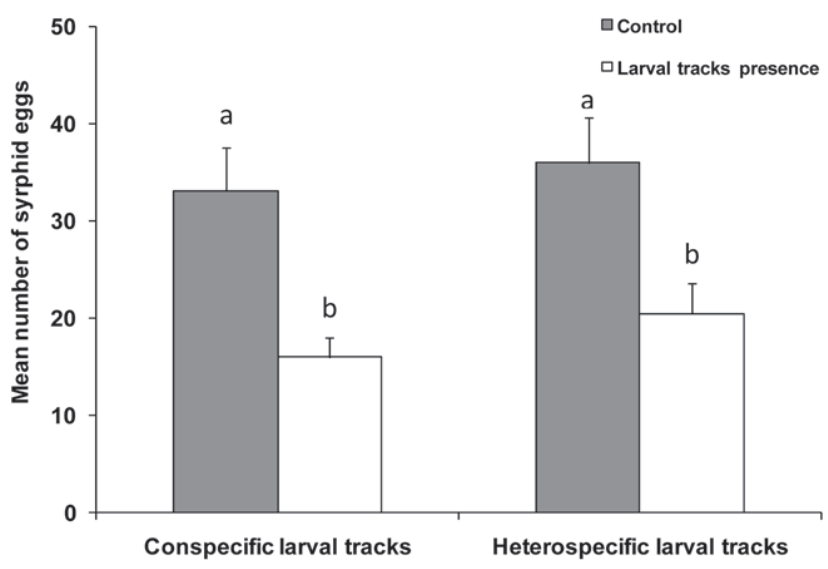

Fig. 1. Mean ( \pm SE) number of eggs laid by E. balteatus females on leaf discs contaminated with the tracks of larvae of their own species or that of larvae of the ladybird H. axyridis compared with a control in two-choice experiments. Means with different letters are significantly different (paired t-test, $\mathrm{P}<$ $0.01)$.

with an excess of aphids (150 individuals) and the number of eggs laid during the next $24 \mathrm{~h}$ was recorded. The control consisted of 10 females kept individually in clean glass Petri dishes that contained a similar number of aphids. The experiment was repeated 10 times for each treatment.

\section{Statistical analysis}

A paired t-test was used to compare the mean number of eggs laid by the aphid predators in the two-choice experiments. In the one-choice experiment, the means were compared using a twosample t-test. All statistical tests were conducted using

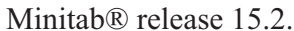

\section{RESULTS}

\section{EXP 1. Effect of conspecific and heterospecific larval tracks on syrphid oviposition}

Gravid E. balteatus females laid significantly fewer eggs on leaf discs on which there were tracks of either conspecific hoverfly larvae (mean $1_{16.00} \pm \mathrm{SE}_{1.99}$ ) (paired t-test, $\mathrm{t}=4.47, \mathrm{P}=0.002$ ) or heterospecific ladybird larvae $\left(\right.$ mean $2_{20.50} \pm \mathrm{SE}_{3.10}$ ) (paired t-test, $\mathrm{t}=3.06, \mathrm{P}=$ 0.014 ) compared to the controls (mean $1_{33.10} \pm \mathrm{SE}_{4.29}$; mean $2_{36.00} \pm \mathrm{SE}_{4.60}$ ) (Fig. 1). Thus the presence of conspecific and heterospecific larval tracks deterred gravid female E. balteatus from ovipositing.

\section{EXP 2. Effect of tracks of syrphid larvae on $\boldsymbol{H}$. axyridis oviposition}

Compared to the control $\left(\operatorname{mean}_{15.50} \pm \mathrm{SE}_{3.10}\right)$, gravid $H$. axyridis females were not deterred from ovipositing by the tracks of E. balteatus larvae $\left(\operatorname{mean}_{15.80} \pm \mathrm{SE}_{3.20}\right)$ (twosample t-test, $\mathrm{t}=-0.07, \mathrm{P}=0.947, d f=18)$ (Fig. 2).

\section{DISCUSSION}

Adults of predators, the larvae of which compete for the same trophic resource, can reduce the intensity of interspecific competition between their larvae by avoiding food resources contaminated with heterospecific semiochemicals (e.g. Růžička, 2001a, b). Several studies have reported lower frequencies of inter- vs. intra-specific 


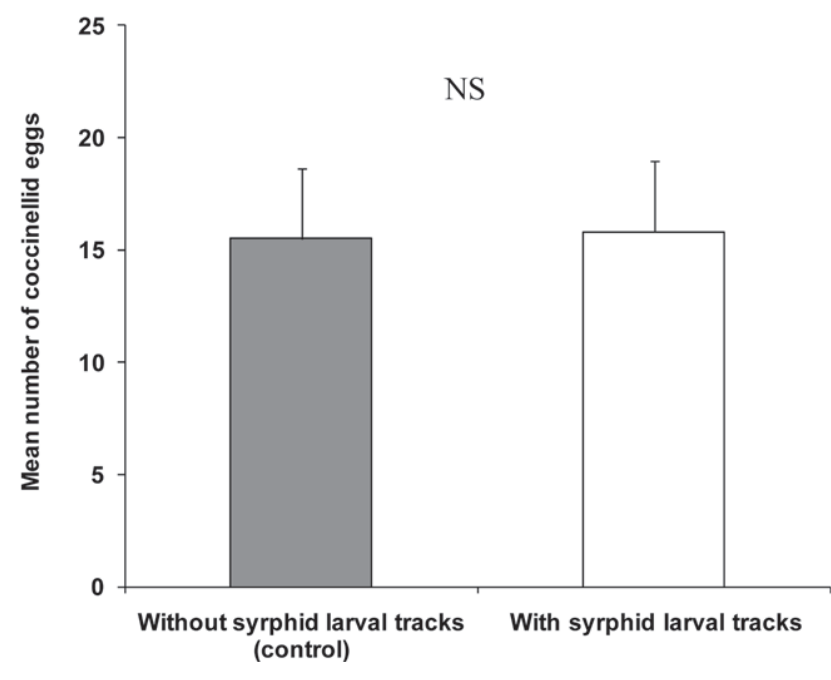

Fig. 2. Mean ( $\pm \mathrm{SE})$ number of eggs laid by $H$. axyridis in Petri dishes containing aphids and contaminated with the tracks left by E. balteatus larvae compared with the average number laid in the control (clean Petri dishes containing only aphids). NS indicates no significant difference between treatments (twosample t-test, $\mathrm{P}>0.05$ ).

interactions in phytophagous insects (Birch et al., 1980; Byers et al., 1984; Thiéry et al., 1992) and parasitoids (Janssen et al., 1995). In insect predators, interspecific interactions occur between chrysopids (Růžička, 1996, 1998) and coccinellids (Růžička, 2001a, b). This study records for the first time interspecific interactions between hoverflies and coccinellids.

In our experiments, E. balteatus females laid fewer eggs when ovipositing in aphid colonies contaminated with the tracks of both conspecific larvae and heterospecific coccinellid larvae. A similar response is also shown by female Coccinella septempunctata L. to tracks left by larvae of both C. septempunctata and Chrysopa oculata Say (Růžička, 1997). Putra et al. (2009) also report that hoverflies tend to reduce their rate of laying eggs when ladybird larvae are present. The mechanism underlying the reduction in oviposition by $E$. balteatus females in the presence of the tracks or larvae of both conspecific and heterospecific predators is unknown. This response is likely to be adaptive as laboratory studies have demonstrated that $H$. axyridis larvae will eat E. balteatus eggs (Alhmedi et al., unpubl. data) and syrphid larvae (Putra et al., 2009).

H. axyridis females are deterred from ovipositing on broad-bean plants contaminated with conspecific larval tracks but not those of $C$. septempunctata larvae (Yasuda et al., 2000). The no-choice tests used here indicate that $H$. axyridis females exhibit a weak response to the presence of oviposition-deterring substances in the tracks of E. balteatus larvae (10 replicates only). It is interesting to speculate why adult ladybirds respond only to conspecific cues. It is likely that each species of ladybird is associated mainly with one particular habitat (Honěk, 1985), where it is more likely to meet individuals of its own species than of other species.
It is well established that females of insects occupying the third trophic level (i.e. parasitoids and predators) avoid ovipositing where competitors threaten the survival of their offspring by responding to the semiochemicals released by conspecific competitors. For example parasitoids are sensitive to volatiles signaling the previous or actual presence of conspecifics and to chemical trails deposited by their enemies (Price, 1970; Janssen et al., 1995; Nakashima et al., 2004). Several aphidophagous and coccidophagous predators respond to ovipositiondeterring semiochemicals in the tracks left by conspecific larvae (Merlin et al., 1996; Růžička, 1997, 2002, 2006; Doumbia et al., 1998; Hemptinne et al., 2001). In our experiments, E. balteatus females laid fewer eggs on leaf discs contaminated with the tracks of conspecific and heterospecific larvae, possibly by responding to a chemical(s) in the tracks (i.e. oviposition - deterrents). Such responses enable females to quickly assess the quality of patches of prey and enhance their probability of discovering suitable oviposition sites.

$E$. balteatus and $H$. axyridis have been used to control aphids in greenhouses (Snyder et al., 2004; Pineda \& Marcos-García, 2008). The present study provides new information on semiochemical spacing of these aphidophagous predators over prey patches of different quality. This knowledge could be employed to improve the effectiveness of these aphid predators when used in biological control programs.

ACKNOWLEDGEMENTS. The authors thank the government of Syria for its financial support of R. Almohamad. We are also grateful to Y. Brostaux from the (GxABT) (Gembloux Agro-Bio Tech, Liège University) for his help with the statistical analysis. This work was funded by a FNRS (Fonds national de la Recherche scientifique) grant (M 2.4.586.04.F).

\section{REFERENCES}

Adriaens T., Branquart E. \& Maes D. 2003: The multicoloured Asian ladybird Harmonia axyridis Pallas (Coleoptera: Coccinellidae), a threat for native aphid predators in Belgium? Belg. J. Zool. 133: 195-196.

Agarwala B.K. \& Yasuda H. 2001: Larval interactions in aphidophagous predators: effectiveness of wax cover as defense shield of Scymnus larvae against predation from syrphids. Entomol. Exp. Appl. 100: 101-107.

Alhmedi A., Haubruge E., Bodson B. \& Francis F. 2007: Aphidophagous guilds on nettle (Urtica dioica) strips close to fields of green pea, rape and wheat. Insect Sci. 14: 419-424.

Almohamad R., Verheggen F.J., Francis F. \& Haubruge E. 2006: Evaluation of hoverfly Episyrphus balteatus DeGeer (Diptera: Syrphidae) oviposition behaviour toward aphidinfested plants using a leaf disc system. Commun. Agric. Appl. Biol. Sci. Ghent Univ. 71: 403-412.

Almohamad R., Verheggen F.J., Francis F. \& Haubruge E. 2007: Predatory hoverflies select their oviposition site according to aphid host plant and aphid species. Entomol. Exp. Appl. 125: 13-21.

Almohamad R., Verheggen F.J., Francis F., Hance T. \& Haubruge E. 2008: Discrimination of parasitized aphids by a hoverfly predator: Effect on larval performance, foraging and oviposition behavior. Entomol. Exp. Appl. 128: 73-80.

Birch M.C., Svihra P., Paine T.D. \& Miller J.C. 1980: Influence of chemically mediated behavior on host tree coloniza- 
tion by four cohabiting species of bark beetles. J. Chem. Ecol. 5: $395-414$.

Byers J.A., Wood D.L., Craig J. \& Hendry L.B. 1984: Attractive and inhibitory pheromones produced in the bark beetle, Dendroctonus brevicomis, during host colonization: regulation of inter- and intraspecific competition. J. Chem. Ecol. 10: 861-877.

Chambers R.J. 1988: Syrphidae. In Minks A.K. \& Harrewijn P. (eds): Aphids, their Biology, Natural Enemies, and Control. World Crop Pests. Elsevier, Amsterdam, pp. 259-270.

Chambers R.J. \& Adams T.H.L. 1986: Quantification of the impact of hoverflies (Diptera: Syrphidae) on cereal aphids in winter wheat: an analysis of field populations. J. Appl. Ecol. 23: 895-904.

ChANDLER A.E.F. 1969: Locomotive behaviour of first instar larvae of aphidophagous Syrphidae (Diptera) after contact with aphids. Anim. Behav. 17: 673-678.

Colignon P., Hastir P., Gaspar C. \& Francis F. 2001: Effet de l'environnement proche sur la biodiversité entomologique en culture maraichères de plein champ. Parasitica 56: 59-70.

Dixon A.F.G. 1985: Structure of aphid populations. Annu. Rev. Entomol. 30: 155-174.

Dixon A.F.G., Hemptinne J.-L. \& Kindlmann P. 1997: Effectiveness of ladybirds as biological control agents: Patterns and processes. Entomophaga 42: 71-83.

DoBZhANSKy T. 1933: Geographical variation in ladybeetles. Am. Nat. 67: 97-126.

Doumbia M., Hemptinne J.-L. \& Dixon A.F.G. 1998: Assessment of patch quality by ladybirds: role of larval tracks. Oecologia 113: 197-202.

Gilbert F. 1993: Hoverflies. Naturalists' Handbooks 5, 2nd ed. Richmond Press, Surrey, $67 \mathrm{pp}$.

Hemptinne J.-L., Dixon A.F.G., Doucet J.-L. \& Petersen J.-E. 1993: Optimal foraging by hoverflies (Diptera: Syrphidae) and ladybirds (Coleoptera: Coccinellidae): mechanisms. Eur. J. Entomol. 90: 451-455.

Hemptinne J.-L., Lognay G., Doumbia M. \& Dixon A.F.G. 2001: Chemical nature and persistence of the oviposition deterring pheromone in the tracks of the larvae of the two spot ladybird, Adalia bipunctata (Coleoptera: Coccinellidae). Chemoecology 11: 43-47.

HonĚK A. 1985: Habitat preferences of aphidophagous coccinellids (Coleoptera). Biol. Control 30: 253-264.

Janssen A., van Alphen J.J.M., Sabelis M.W. \& BaKker K. 1995: Odour-mediated avoidance of competition in Drosophila parasitoids: the ghost of competition. Oikos 73: $356-366$.

KAN E. 1988: Assessment of aphid colonies by hoverflies. I. Maple aphids and Episyrphus balteatus (DeGeer) (Diptera: Syrphidae). J. Ethol. 6: 39-48.

Kindlmann P. \& Dixon A.F.G. 1993: Optimal foraging in ladybird beetles and its consequences for their use in biological control. Eur. J. Entomol. 90: 443-450.

Косн R.L. 2003: The multicoloured Asian lady beetle, Harmonia axyridis: a review of its biology, uses in biological control and non-target impacts. J. Insect Sci. 3: 1-16.

Kuznetsov V.N. 1997: Lady Beetles of Russian Far East. The Sandhill Crane Press, Gainesville, FL, 244 pp.

LeE J.H. \& KANG T.J. 2004: Functional response of Harmonia axyridis (Pallas) (Coleoptera: Coccinellidae) to Aphis gossypii Glover (Homoptera: Aphididae) in the laboratory. Biol. Control 31: 306-310.

Merlin J., Lemaitre O. \& Grégoire J.-C. 1996: Chemical cues produced by conspecific larvae deter oviposition by the cocci- dophagous ladybird beetle, Cryptolaemus montrouzieri. Entomol. Exp. Appl. 79: 147-151.

Michaud J.P. \& Jyoti J.L. 2007: Repellency of conspecific and heterospecific larval residues to Hippodamia convergens (Coleoptera: Coccinellidae) ovipositing on sorghum plants. Eur. J. Entomol. 104: 399-405.

Miñarro M., Hemptinne J.-L. \& Dapena E. 2005: Colonization of apple orchards by predators of Dysaphis plantaginea: sequential arrival, response to prey abundance and consequences for biological control. BioControl 50: 403-414.

Nakashima Y., Birkett M.A., Pye B.J., Pickett J.A. \& Powell W. 2004: The role of semiochemicals in the avoidance of the seven-spot ladybird, Coccinella septempunctata, by the aphid parasitoid, Aphidius ervi. J. Chem. Ecol. 30: 1103-1116.

Oliver T.H., Timms J.E.L., TAYlor A. \& Leather S.R. 2006: Oviposition responses to patch quality in the larch ladybird Aphidecta obliterata (Coleoptera: Coccinellidae): effects of aphid density, and con- and heterospecific tracks. Bull. Entomol. Res. 96: 25-34.

Pell J.K., Baverstock J., Roy H.E., Ware R.L. \& Majerus M.E.N. 2008: Intraguild predation involving Harmonia axyridis: a review of current knowledge and future perspectives. BioControl 53: 147-168.

Pineda A., Morales I., Marcos-García M.A. \& Fereres A. 2007: Oviposition avoidance of parasitized aphid colonies by the syrphid predator Episyrphus balteatus mediated by different cues. Biol. Control 42: 274-280.

Pineda A. \& Marcos-García M.A. 2008: Evaluation of several strategies to increase the residence time of Episyrphus balteatus (Diptera, Syrphidae) releases in sweet pepper greenhouses. Ann. Appl. Biol. 152: 271-276.

PrICE P.W. 1970: Trail odors: recognition by insects parasitic on cocoons. Science 170: 546-547.

Putra N.S., Yasuda H. \& Sato S. 2009: Oviposition preference of two hoverfly species in response to risk of intraguild predation. Appl. Entomol. Zool. 44: 29-36.

Roy H.E., Brown P. \& Majerus M.E.N. 2006: Harmonia axyridis: a successful biocontrol agent or an invasive threat? In Eilenberg J. \& Hokkanen H. (eds): An Ecological and Societal Approach to Biological Control. Springer, Dordrecht, pp. 295-309.

RŮŽIČKA Z. 1994: Oviposition-deterring pheromone in Chrysopa oculata (Neuroptera: Chrysopidae). Eur. J. Entomol. 91: 361-370.

RŮŽIČKA Z. 1996: Oviposition-deterring pheromone in Chrysopidae (Neuroptera): Intra- and interspecific effects. Eur. J. Entomol. 93: 161-166.

RƯŽIČKA Z. 1997: Recognition of oviposition-deterring allomones by aphidophagous predators (Neuroptera: Chrysopidae, Coleoptera: Coccinellidae). Eur. J. Entomol. 94: 431-434.

RŮŽIČKA Z. 1998: Oviposition-deterring allomone in Chrysopids (Neuroptera: Chrysopidae). Eur. J. Entomol. 95: 35-39.

RŮŽIČKA Z. 2001a: Oviposition responses of aphidophagous coccinellids to tracks of ladybird (Coleoptera: Coccinellidae) and lacewing (Neuroptera: Chrysopidae) larvae. Eur. J. Entomol. 98: $183-188$.

RƯŽIČKA Z. 2001b: Response of chrysopids (Neuroptera) to larval tracks of aphidophagous coccinellids (Coleoptera). Eur. J. Entomol. 98: 283-285.

RŮŽIČKA Z. 2002: Persistence of deterrent larval tracks in Coccinella septempunctata, Cycloneda limbifer, and Semiadalia undecimnotata (Coleoptera: Coccinellidae). Eur. J. Entomol. 99: $471-475$. 
RŮŽIČKA Z. 2006: Oviposition-deterring effects of conspecific and heterospecific larval tracks on Cheilomenes sexmaculata (Coleoptera: Coccinellidae). Eur. J. Entomol. 103: 757-763.

RŮŽIČKA Z. \& HAVELKA J. 1998: Effects of oviposition-deterring pheromone and allomones on Aphidoletes aphidimyza (Diptera: Cecidomyiidae). Eur. J. Entomol. 95: 211-216.

Scholz D. \& Poehling H.-M. 2000: Oviposition site selection of Episyrphus balteatus. Entomol. Exp. Appl. 94: 149-158.

Snyder W.E., Ballard S.N., Yang S., Clevenger G.M., Miller T.D., Ahn J.J., Hatten T.D. \& Berryman A.A. 2004: Complementary biocontrol of aphids by the ladybird beetle Harmonia axyridis and the parasitoid Aphelinus asychis on greenhouse roses. Biol. Control 30: 229-235.

Tenhumberg B. \& Poehling H.M. 1991: Studies on the efficiency of syrphid larvae, as predators of aphids on winter wheat. In Polgar L., Chambers R.J., Dixon A.F.G. \& Hodek I. (eds): Behaviour and Impact of Aphidophaga. SPB Academic Publishing, The Hague, pp. 281-288.

Thiéry D., Gabel B. \& Pouvreau A. 1992: Semiochemicals isolated from the eggs of Ostrinia nubilalis as oviposition deterrent in three other moth species of different families. In Menken S.B.J., Wisser J.H. \& Harrewijn P. (eds): Proc. 8th Int. Symp. Insect-Plant Relationships. Kluwer Acad. Publ., Dordrecht, pp. 149-150.

Yasuda H., TAKagi T. \& Kogi K. 2000: Effects of conspecific and heterospecific larval tracks on the oviposition behaviour of the predatory ladybird Harmonia axyridis (Coleoptera, Coccinellidae). Eur. J. Entomol. 97: 551-553.

Received May 20, 2009; revised and accepted October 26, 2009 